\title{
The critical landscapes identification: Radioecological approach
}

\author{
N. Grytsyuk
}

\author{
Ukrainian Institute of Agricultural Radiology (UIAR), Chabany, \\ St. Mashinostroiteley 7, 08162 Kiev, Ukraine
}

\begin{abstract}
A new approach to identification of radiological criticacy of landscapes in radioactive contaminated lands by estimated dependence between landscape conditions and ${ }^{137}$ Cs soil-to-plant transfer factor (TF) was revealed. A map of TF values for meadow caenoses on abandoned agricultural lands reflected radiological criticacy of the area was built.
\end{abstract}

\section{INTRODUCTION}

Radiological criticacy of the landscapes under the equal radioactive contamination is determined by the significant intensity of biogenic migration of the radionuclides promoting the dose loadings increase due to their inclusion into the food chains. Just contribution of the landscape area into the dose formation determines its criticacy [1-2].

Dose loading per buman body in a remote post-accidental period in the Chernobyl NPP zone is conditioned by internal irradiation mainly due to consumption of radionuclide contaminated agricultural products. The main mechanism of products contamination both of plant, and animal origin is biogenic migration of the radionuclides in a soil-plant chain. Intensity of this process is determined by soilchemical conditions, peculiarities of plant cover, structure of land-use [3-6], forming a landscape in combination, hence the process is depended upon a landscape.

Numeral characteristic of intensity of radionuclides uptake by plants from soil is represented by the transfer factor (TF). According to our conclusions [7], experimentally estimated TF values depend on landscape conditions of the study area, therefore radionuclides transfer factor into phytomass could be considered as a quantitative characteristic and criteria for identification of the radiologically critical landscapes.

Correct use of such an empiric factor as TF in the radioecological tasks solution is proposed to adhere several verge conditions regulated by methodology of the sampling. Uneven contamination and heterogeneity of the landscapes on the territory under investigation should be taken into account during sampling. That means counting of earth surface relief, differences of litology of up ground and under spread soil-forming deposits and types of growing place conditions, and therefore, soil-plant cover and type of land-use which determine landscape diversity of the radioactive contaminated territory in combination.

Assessment of radioecological criticacy of landscapes is made for lands withdrawn from use due to high levels of their radioactive contamination after the Chernobyl accident in Narodychi district, Zhytomyr province. Narodychi district is one of the mostly radioactive contaminated ones; it is the typical for northern Ukraine by the landscape structure. ${ }^{137} \mathrm{Cs}$ are the main dose forming radionuclide here.

Studies were carried out in the typical landscape areas on withdrawn agricultural lands characterised by associations of sown grasses on the former arable lands and natural meadow caenosis due to various radioactive contamination levels. Landscapes of moraine-fluvioglacial plains and river terraces with different litological construction, drainage, different types of growing conditions, soils and 
caenosis are distributed in Narodychi district. Special attention was paid to geochemically conjugated landscapes and those ones differed by hydromorphousness of soils.

\section{RESULTS AND DISCUSSION}

Results of studies of $\mathrm{Cs}^{137}$ soil-plant transfer factor dependence upon landscape structure of the area during three years (1998 2000) show that such integral characteristic of biogenic radionuclide migration as TF correlates strongly with the landscape structure of territory [2, 7]. Consequent analysis and summarising of data allowed obtaining the following table as an algorithm for the legend to TF map elaboration on the base of landscape approach.

Data presented in the table show, that the lowest criticacy is specified for automorphous soils with low $T F$ values, their meanings mount to $0,1-0,2$ for sown grasses, and $0,2-0,3$ for natural meadow coenosis. They were estimated for soddy-podzolic sandy loamy and loamy non-gleish soils of the river terraces and moraine-fluvioglacial plains. These soils of the Northern Ukrainian Woodland are characterised by highest natural fertility and favourable water-physical properties. Moreover, these soils are typical for landscape areas occupying relatively raised, well drained locations with relatively good conditions of surface washing-off and additive potential of self-cleaning from radionuclides due to horizontal outflow during a long-term period. These areals as low critical ones in radiological aspect could be considered as mostly attractive ones for the rehabilitation activity.

Average TF values equal to $0,2-1,0$ for sown grasses and $0,3-3,0$ for natural meadows are usual to soddy-podzolic sandy loam and loamy gleish soils, soddy-podzolic sandy soils gleic to different extent and alluvial soddy gleic loamy soils. This group includes soils significantly differed by fertility and their position in landscape.

The third group includes soils with highest values of $\mathrm{TF}$, as peaty gleic, peat bog and alluvial peat bog soils. Transfer factor values in these soils mount to $3,0-10,0$ for sown grasses and $10,0-80$ for meadow coenosis. Alluvial soddy gleic sandy soils draw near to organogenic alluvial ones by high $\mathrm{TF}$ values. So, the highest level of radiological criticacy is characteristic for landscape areals in low located territories of hydromorphic type. Level of hydromorphousness (automorphousness) is determined not only by the type of soil, but also by the location in a relief, hydrological regime, and the type of plant association. By whole natural properties these areals are considered to be low suitable for use even in conditions of low radioactive contamination.

Extent of soil cultivation influences significantly on ${ }^{137} \mathrm{Cs}$ plant to soils transfer. At the same landscape conditions ${ }^{137} \mathrm{Cs}$ TF for sown grasses on cultivated soils and in natural caenosis on noncultivated ones can differ more then to the order of magnitude.

Data obtained show that the same radiological criticacy level can be observed for landscape areals with different enough types of soils and plant association formed in various types of relief, but similar by conditions of growing place (fertility of soils and humidity conditions). This fact shows, that landscape influence due to completeness of natural factors is very important; hence it is very difficult to reveal the mostly important one. The last one concerns meadow coenosis especially, characterised by wide ecological amplitude.

The next step predetermined by estimated regularity between $\mathrm{TF}$ and landscape structure of territory became the cartographic interpretation of the factor values space distribution on the base of the landscape map. On the table data presented above the map of TF for withdrawn agricultural lands of Narodichi district (Fig. 1) in MapInfo was built. 
Table 1. Meanings of the transfer factor of Cs-137 for the phytomass of the natural and cultivated grass associations depending on the landscape areals (legend of map)

\begin{tabular}{|c|c|c|}
\hline $\begin{array}{l}\text { Meanings } \\
\text { of Tf }\end{array}$ & $\begin{array}{l}\text { Soils and landscape areals under cultivated } \\
\text { grass associations }\end{array}$ & $\begin{array}{l}\text { Soils and landscape areals under natural } \\
\text { grass associations }\end{array}$ \\
\hline $0,1-0,2$ & $\begin{array}{l}\text { Moraine-fluvioglacial plains and river } \\
\text { terraces with soddy-podzolic loamy soils, } \\
\text { covered by permanent grass associations } \\
\text { with predomination of Dactylis glomerata } L \text {. }\end{array}$ & \\
\hline$\overline{0,2-0,3}$ & $\begin{array}{l}\text { Moraine-fluvioglacial plains, river terraces } \\
\text { and flood plains with soddy-podzolic dusty- } \\
\text { sandy and loamy gleyish soils, covered by } \\
\text { permanent grass associations with } \\
\text { predomination of herbs }\end{array}$ & $\begin{array}{l}\text { Moraine-fluvioglacial plains and river } \\
\text { terraces with soddy-podzolic loamy soils, } \\
\text { covered by meadows with predomination } \\
\text { of herbs and legumes }\end{array}$ \\
\hline $0,3-1,0$ & $\begin{array}{l}\text { Moraine-fluvioglacial plains, watershed } \\
\text { catchments, river terraces and flood plains, } \\
\text { balkas and dells with soddy-podzolic and } \\
\text { soddy dusty-sandy and loamy gleish, gleyic } \\
\text { and gley soils, covered by permanent grass } \\
\text { (herb) associations }\end{array}$ & $\begin{array}{l}\text { Moraine-fluvioglacial plains, river terraces } \\
\text { and flood plains with soddy-podzolic } \\
\text { dusty-sandy and loamy gleyish soils, } \\
\text { covered by meadows with predomination } \\
\text { of xerophytous herbs }\end{array}$ \\
\hline $1,0-3,0$ & $\begin{array}{l}\text { Lowered moraine-fluvioglacial plains, } \\
\text { watershed catchments, river terraces and } \\
\text { flood plains, balkas, dells and depressions } \\
\text { with soddy-podzolic sandy gley soils and silt } \\
\text { bog soils, covered by permanent grass herb- } \\
\text { legume associations }\end{array}$ & $\begin{array}{l}\text { Moraine-fluvioglacial plains, watershed } \\
\text { catchments, river terraces and flood plains, } \\
\text { balkas and dells with soddy-podzolic and } \\
\text { soddy dusty-sandy and loamy gleyish, } \\
\text { gleyic and gley soils, alluvial gleyish } \\
\text { loamy soils, covered by meadows with } \\
\text { predomination of herb and herb-legume } \\
\text { associations }\end{array}$ \\
\hline $3,0-10,0$ & $\begin{array}{l}\text { Lowered drained river terraces and flood } \\
\text { plains with peat bog soils, covered by } \\
\text { permanent grass herb-legume associations }\end{array}$ & $\begin{array}{l}\text { Moraine-fluvioglacial plains, watershed } \\
\text { catchments, river terraces and flood plains, } \\
\text { balkas and dells with soddy-podzolic and } \\
\text { soddy sandy gley soils and drained peaty } \\
\text { soils, covered by meadows with } \\
\text { predomination of herb and herb-legume } \\
\text { associations }\end{array}$ \\
\hline $10,0-20,0$ & - & $\begin{array}{l}\text { Lowered drained river terraces and flood } \\
\text { plains with (alluvial) drained and non- } \\
\text { drained peaty soils, covered by meadows } \\
\text { with predomination of grasses, herbs and } \\
\text { sedges }\end{array}$ \\
\hline $20,0-80 \ldots$ & - & $\begin{array}{l}\text { Lowered drained river terraces and flood } \\
\text { plains with (alluvial) non-drained peat bog } \\
\text { soils, covered by herb-sedgeous meadows }\end{array}$ \\
\hline
\end{tabular}




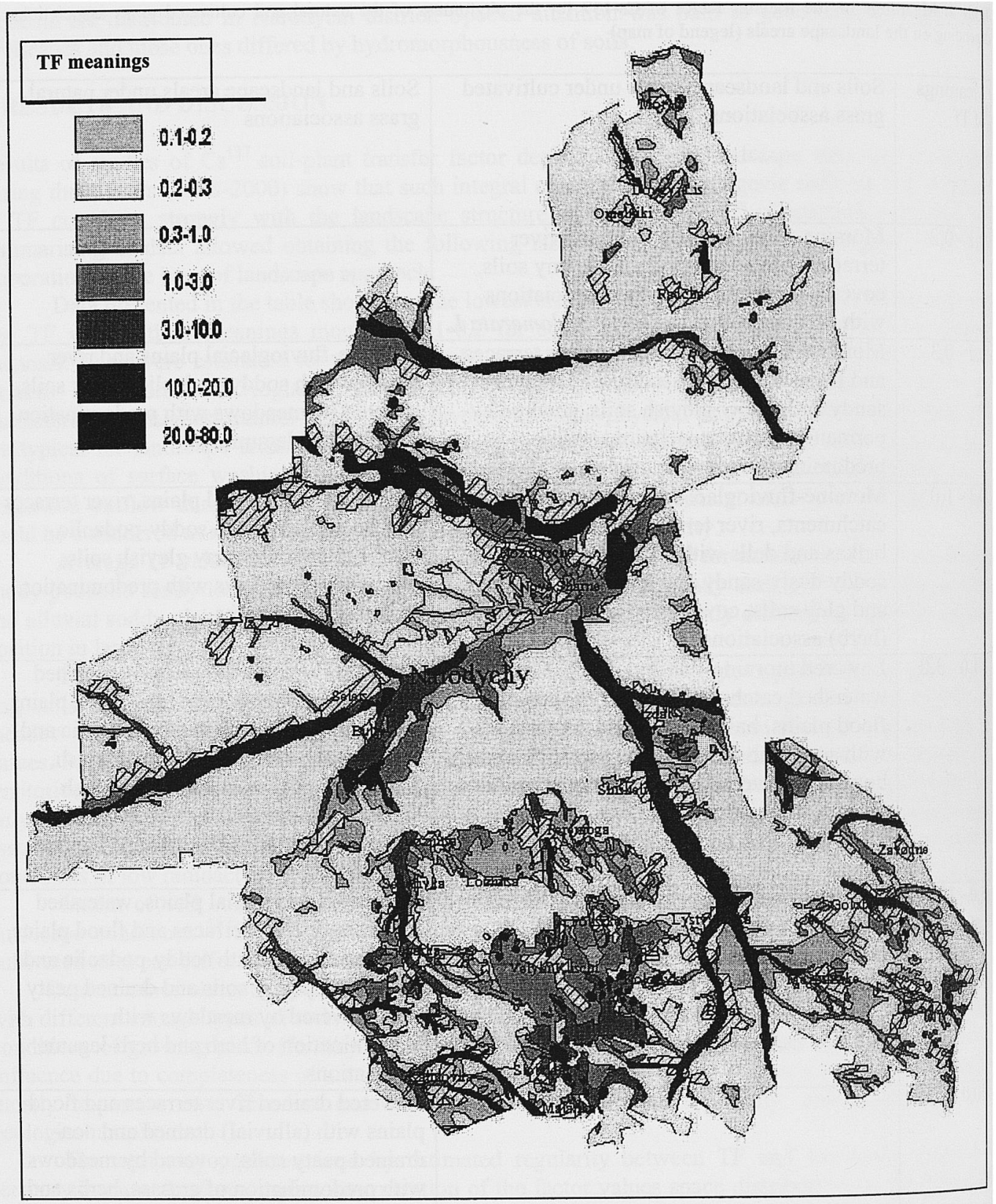

Scale $1: 300000$

Figure 1. Meanings of $\mathrm{Tf}^{137} \mathrm{Cs}$ for the natural and cultivated grass associations (see table 1.). Narodychi district, withdrawn agricultural lands 


\section{CONCLUSIONS}

The obtained map allows to characterise the radiological criticacy of territories by the TF values.

The map allows to characterise regularities of the TF space distribution for the meadow and sown grasses and can be used for solution of the complete radioecological fundamental and applied tasks founded on biogenic radionuclide migration.

\section{Acknowledgments}

The author is grateful to V. Davydchuk (UIG, Kiev) for useful discussion and great assistance.

\section{References}

[1] European Commission. EUR 16531 - The behaviour of radionuclides in natural and semi-natural environments. Eds. M.Belli and F.Tikhomirov. Luxembourg: Office for Official Publications of the European Communities, 1996,147 pp.

[2] Grytsyuk N. Dependence of $\mathrm{Cs}^{137}$ transfer factor for grass on the landscape structure of territory. Visnyk agrarnych nauk. № 4, 2001, p.97-99 (in Ukrainian)

[3] Landscapes of Chernobyl zone and their estimation on radionuclides migration conditions. Edited by A. Marinich. Kiev, Naukova Dumka, 1994, 112 p. (in Russian).

[4]. Sorokina L. On accumulation of $\mathrm{Cs}^{137}$ by phytocomponents of forest ecosystems depending on edaphotop conditions. Ukrainian Geographic Journal, 1996, №1, pp. 44-48(in Ukrainian)

[5] Prister B., Loschilov N., Nemets O., Pojarkov V. Foundation of agricultural radiology. - Kiev. 1991. (In Russian).

[6] Prister B., Vynogradska V., Study correlation of the agricultural products contamination from the agrochemical and radiological characteristics of the soil. In: Proceedings of the conference "Science. Chomobyl-98", Kyiv, 1999, p.152 (in Ukrainian)

[7] Davydchuk V., Grytsyuk N., Landscape approach to the rehabilitation of the territories contaminated atter the Chernobyl accident. In: Proceedings of the conference "Modern problems of radiobiology, radioecology and evolution" dedicated to centenary of N.W. Timofeeff-Resovsky", Dubna, 2000, p.174. 